\title{
G.J.V. Prasad, ed. India in Translation, Translation in India.
}

\section{Cécile Girardin}

\section{(2) OpenEdition \\ 1 Journals}

Electronic version

URL: https://journals.openedition.org/ces/1627

DOI: $10.4000 /$ ces. 1627

ISSN: 2534-6695

Publisher

SEPC (Société d'études des pays du Commonwealth)

Electronic reference

Cécile Girardin, "G.J.V. Prasad, ed. India in Translation, Translation in India.", Commonwealth Essays and Studies [Online], 42.2 | 2020, Online since 30 September 2020, connection on 18 January 2022. URL: http://journals.openedition.org/ces/1627 ; DOl: https://doi.org/10.4000/ces.1627

This text was automatically generated on 18 January 2022.

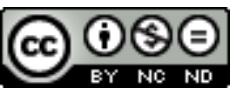

Commonwealth Essays and Studies is licensed under a Licence Creative Commons Attribution - Pas d'Utilisation Commerciale - Pas de Modification 4.0 International 


\title{
G.J.V. Prasad, ed. India in Translation, Translation in India.
}

\author{
Cécile Girardin
}

\section{REFERENCES}

New Delhi: Bloomsbury India. 325 p. ISBN: 978938841 4203. \$103.50.

1 G.J.V. Prasad introduces his new volume by playfully listing the various names used to refer to India, initially derived from the river Sindhu, later called Indus by foreigners, while other names, like Bharat and Hindustan, still persist in everyday speech. He points at the very flexible, and at times contradictory use of the lexicon, with the word Hindustan belonging both to Muslim rule during the Mughal period and to Hindu extreme-right discourse in more recent history.

Multilingual India, where governance depends on translation, boasts sixteen hundred languages and dialects, and the Indian constitution recognizes a list of twenty-two languages. Among them, Sanskrit, Tamil, Malayalam, Telugu, Kannada and Odia are officially given the status of "classical" languages on the basis of their proven literary existence for a considerably long time, whereas Hindi and English, while not appearing in the list cited above, are deemed the "official" languages of the nation.

The present volume deals with the subject of translation of and in India, and its authors scrutinize the effect of translation on the construction of the idea of India for the last two hundred years. In other words, they look at "how Indian texts travel around the world in translation and how Indian texts travel across languages in the subcontinent, and how texts from various languages of the world travel to India" (xv). To achieve this, the book comprises no less than eighteen chapters written as a series of case studies arranged without any obvious order, ranging from the translation of the Aeneid, Kafka or Kabir, to specific issues pertaining to transgender literature or Jesuit conversion in the eighteenth century. Such a vast outlook allows for a polymorphous, 
yet fascinating reading, opening a great number of research paths for anyone interested in India, translation, and Indian translation.

The book's structure would have benefited from a more problematized chaptering, given that the reader will find material addressing three major questions that randomly crop up throughout the book: translation as an instrument of colonialism and anticolonialism, translation as a tool of empowerment and emancipation from English, and translation as transcreation, following the idea of David Damrosh that an excellent translation can be seen as an expansive transformation of the original, adding a new stage in the life of a work as it moves from its first home out into the world (quoted page 300).

During the period of colonialism, legal, religious and literary texts were selected for translation, allowing colonizers to perpetuate relations of power and to project a distorted picture of the Orient. Chapters 2, 4, 9, 10, 11 and 13 posit the utilitarian dimension of translation through the analysis of its praxis since colonial times. The story of the Hindu Widows' Remarriage Act of 1856 is interpreted by Gargi Bhattacharya as a series of translating strategies to meet the colonizers' agenda. A most fascinating case related by Tara Menon shows how Jesuit priests forged a translation from French to Sanskrit of a supposedly supplementary Veda, called the Ezourvedam, in order to conduct their conversion tasks more efficiently, which, in an unexpected turn of fate, also served Voltaire's purpose of vilifying Catholicism. The book is at its best when it makes clear that translations are never released in a political vacuum, and Shinjini Basu alludes to the timeliness of translations of Gramsci into Bengali in the 1990s, when Indian politics dramatically needed renewal. In his study of Tagore's translations of ascetic medieval saint-poet Kabir into Bengali and English, Amitendu Bhattacharya demonstrates how the Nobel laureate worked at constructing a consistent lineage leading to his own political idealism, thereby proving that a strong secular tradition existed in India long before the British arrived. Similarly, looking at the translations of some French authors (such as Hugo, Maupassant, Dumas) from the 1850s onwards across Indian languages, Nipun Nutan underlines a consistent, yet never fulfilled desire to find alternative models to English cultural and political references.

Chapters 1, 3, 8, 16 and 17 all address translation from and to Indian basha ${ }^{1}$ languages, as a way to give voice to a specific community and to endow it with a history and an agenda of its own, while at the same time contributing to decentering both Sanskrit and English. The thirteenth-century translation of the Bhagwad Gita into Marathi is a case of vernacularization which gave rise to Marathi written literature. In the mid-1850s, a translation of Aristophanes into Gujarati fostered the emergence of a Gujarati literary sphere. Subhendu Mund, who studies some translations of classic tales and fables, shows how a major part of Indian literature was constituted of translations within basha languages, independently from English, debunking the entrenched habit of associating translation in India with colonial or anticolonial exercises. The final chapters of the volume suggest that translation is necessary to uphold the emancipatory project inherent to hijra ${ }^{2}$ literature and the narratives of disability, which can contribute to making India more egalitarian, by reaching out to its remotest parts.

7 The third thread running through the book concerns translation as transcreation in chapters $5,6,7,12,15$, which raise relevant questions on self-definition and the emergence of an idea of India through what is gained, lost, and transformed in the 
process. Case studies concerning the translation of a Medieval Bengali Mahabharata into English, of the Aeneid into Bengali, of the Panchatantra into English and Grimm's Fairy Tales into Asian languages, all highlight how the texts were naturalized at various times in history, that is to say significantly edited to comply with the culture of reception, thereby showing to what extent translation is dependent on religion and on the reading practices of their time. Similarly, in the contemporary period, translations of Beckett and Kafka enabled their Indian translators to meditate on the artists' inherent anguish about language in order to elaborate their own linguistic and poetic practices.

Unfortunately, some contributions lack the necessary scholarship needed to support convincing arguments. Such is the case of Runjhun Verma's essay on the 2001 translation anthology of Indian vernacular literature into French, published by the literary review Europe. It fails to consider issues of reception, since Europe is hardly representative of the French reading public as a whole, whereas at that exact same time in France the rise of the English-language Indian novel was significantly reshaping representations of India, a phenomenon the author chooses to ignore. Had some of the authors accepted to engage in historical and philosophical debates about the competition of languages in India, the special role of Hindi, but also about postcolonialism itself, a notion often eschewed in the book, some of the chapters would have reached another level of complexity. The excellent piece on Tagore reminds one of Amit Chaudhuri's 2008 thought-provoking book on modernity in India and Bengal in particular, and makes the reader wish the book had made more consistent connections with contemporary thought.

\section{NOTES}

1. Regional languages.

2. In India, hijras are eunuchs, intersex and transgender people.

\section{AUTHORS}

\section{CÉCILE GIRARDIN}

Université Sorbonne Paris Nord

Cécile Girardin is a Senior Lecturer at University Sorbonne Paris Nord. She specializes in postcolonial literatures and is the author of Continuité, conservatisme, classicisme dans les littératures postcoloniales (Presses Universitaires de Rennes, 2013), as well as articles on the fiction and essays of Salman Rushdie, V.S. Naipaul, Anita Desai, Mohsin Hamid, Amitav Ghosh and Nirad Chaudhuri. 